\title{
NON-FORMAL MANAGEMENT EDUCATION: SOME EVIDENCE FROM MANAGEMENT TRAINING BUSINESSES WEBSITES IN ESTONIA
}

\author{
Maret Ahonen \\ University of Tartu, Tartu, Estonia \\ E-mail: maret.ahonen@ut.ee
}

\begin{abstract}
Management education and MBA programs have been criticized for being rigor and having little effect on managerial performance, however little attention has been paid to management education provided by management training and development businesses often referred to as non-formal education providers. Since the studies on management training businesses are scarce, the exploratory study was conducted documenting the state of management training businesses' activities in Estonia on the analysis of four focus issues: (1) the scope of training programs; (2) methods; (3) trainers and (4) organizational development. The data was collected from 26 management training businesses' websites including 3 universities' continuing education websites. The findings highlight the domination of soft skills, coaching as an increasingly used method, frequent use of contracted co-trainers and modest reflection of organizational development issues.

The outcome contributes to the literature of management education, training and developing research providing preliminary insight on management training businesses activities. Additionally the results could be of practical use for HR managers in assessing overall capabilities of management training businesses.
\end{abstract}

Key words: management training and development, non-formal management training, methods, programs, trainers.

\section{Introduction}

Management education and development are overlapping yet distinguished notions. Fox (1997, p. 21) finds that management education is a term referring largely to learning provided by university business and management schools whereas management development is "provided by public sector in a form of in-house management development, training and development, and/or HRD departments of organizations assisted by numerous freelance consultants, small and large training businesses". Training businesses are often seen as representatives of nonformal education providers, yet boundaries between formal and non-formal education are blurry (Rogers, 2005). Non-formal education has been defined by Coombs and Ahmed (1974, p. 8) as: "any organised, systematic, educational activity carried on outside the formal system to provide selected types of learning to particular subgroups in the population, adults as well as children" and formal education: "the highly institutionalised, chronologically graded and hierarchically structured "education system", spanning lower primary school and the upper reaches of the university".

In the view of the given definition university represents formal education however their business and management schools programs have been often criticized for not being related 
PROBLEMS

OF MANAGEMENT

IN THE $21^{\text {st }}$ CENTURY

Volume 4, 2012

with practice (Colby, Ehrlich, Sullivan \& Dolle, 2011; Datar, Garvin \& Cullen, 2010; Minzberg, 2004). At the same time Yiu and Saner (2009) find that non-formal management education has eluded the critical eye of management scholars and suggest accreditation of non-formal education. The current article agrees with the view that non-formal management education has been not enough studied thus it explores management training businesses' websites aiming to map their scope of activities in Estonia.

Despite the understanding that monkeys, dentists and doctors can be trained but managers developed (Paauwe and Williams (2001, p. 90), in management education literature and practice the term management training usually comes up in the context of development. Training is seen as job specific skill acquisition (Ajuogu, 1993; Indradevi, 2010) contributing into the wider field of management development. Compared with development training is considered a time-framed activity with clear organizational focus whereas development is an open-ended and long-term process (McDowall \& Saunders, 2010), which according to Gray and Mabey (2005) has positive impact on firm's performance. Mabey and Finch-Lees (2008, p. 37) have placed both: management education and management development together with training into the broader prism of management learning.

Training businesses have clear role in management development since they are often looked for their ability to turn theoretical models into practical use in a specific context and in a limited time frame. Understanding company specific enables training companies to design training programs, known as tailor made programs. Moreover, tailor made programs can be brought into the organization. Minzberg (2011) suggests that management training at workplace enables to develop the whole organization while its leaders are trained. Tailor made program allows flexibility and instant reflection on issues of concern to the participants. Berggren and Söderlund (2011) find that such a true reflection can take place in the conditions of perceived trust and meaningful context only. This means that effectiveness of a training program depends much on trainer's skills and qualification, his/her ability to use training techniques and methods. Not less important is also trainers relationship with training business - the extent to what they perceive support as well as identify themselves with their employer. However it is well-known practice that training businesses often use contractors and ask experienced managers for their reputation to conduct courses. Yiu and Saner (2009) see this as a shortcoming because their teaching is rich in anecdotes but poor in reflection and in conceptualization skills. It can be true in many cases since practitioners might have little if any preparation and knowledge on methodologies of teaching adult learners. On the other hand they bring real-life situations into the training process and generate experience sharing.

Managerial skills: technical, human and conceptual, the categorization proposed by Robert Katz are generally recognized as a source of competitive advantage when handled with great care and taken seriously (Longenecker \& Fink, 2005). Teaching skills is often approached through the spectrum of managerial roles described by Henry Minzberg thus referring to an ideal managerial behavior. Andersson (2008) argues that such an ideal-type is often represented in management training, but as management is very context specific thus training should be related with context. A way to relate training and context is the use of personal development and executive coaching as a method. The use of the method is increasing in management training thus making programs more meaningful at the time when for example MBA programs are being criticized for taking theory and research out of context (Barnett, 2007) and having little relevance of research to practice (Datar, et al., 2011).

As for skills a survey in UK showed that managers are planning to develop their skills in strategic decision making, networking, coaching and mentoring followed by project management and communication (Ketter, 2011). The most critical skills according to the Estonian executives in 2009 were: improving leadership development, managing talent, measuring workforce performance, strategic planning of the workforce, becoming a learning organization (Creating 
People Advantage 2009). Teamwork and cooperation competencies as well as sales training (Table 1) were top training needs stressed by managers in Estonia in post-financial crises period (Enterprise Estonia 2011).

Table 1. Executives views on topics to be focused at trainings across two studies conducted in Estonia in 2009 and in 2011.

\begin{tabular}{|c|c|}
\hline $\begin{array}{c}\text { Results of the study } \\
\text { (Creating People Advantage 2009) }\end{array}$ & $\begin{array}{c}\text { Results of the study } \\
\text { (Enterprise Estonia 2011) }\end{array}$ \\
\hline \multicolumn{2}{|c|}{} \\
\hline Improving leadership development & Teamwork \\
\hline Managing talent & Cooperation competencies \\
\hline Measuring workforce performance & Sales skills \\
\hline Strategic planning of workforce & \\
\hline Becoming a learning organization. & \\
\hline
\end{tabular}

Here the research question emerges - to what extent relevant knowledge is available on Estonian non-formal management training programs? What are the topics of programs and methods offered to managers and who are the trainers? In order to gain understandings of the state on non-formal management education the author of the current article developed framework for an exploratory study by reviewing training companies' websites and identifying: (1) the scope of programs, (2) methods; (3) information about trainers and (4) the extent to what training companies are reflecting their organizational development. Websites have been extensively studied applying several evaluation categories like webpage design, visual form and functionality. In social science the focus has been on website communication (Sharp, 2001), impression experience (Vorvoreanu, 2008) content and usage (Xi et al., 2007; Knezevic, Renko \& Bach, 2011). The current exploratory study results shed light on management training business activities in terms of - programs, methods, trainers' background and in addition training business's development issues presented on websites are discussed. The results of the exploratory study can be used by HR and training managers and for researchers in gaining preliminary insight of management training and development provided by training businesses in Estonia.

\section{Management Training}

Training is mostly viewed as an investment leading to business competitiveness, personal growth (Aspin \& Chapman, 2000; Gardiner \& Kline, 2007) and business performance (Patterson et al., 1997). Management training and development has been seen by Klein and Ziegert (2004) as the process by which people acquire various skills and knowledge that increases their effectiveness in leading and leadership, guiding, organizing, and influencing others (Powell \& Yalcin, 2008). It is recognized that training not only develops skills but also helps optimum utilization of human resource (Indradevi, 2010). Therefore organizations have little choice but to focus attention and resources on their management training programs if they are willing to compete in the global marketplace of the twenty-first century (Longenecker \& Fink 2005, p. 73).

Training programs build skills, teach concepts, and encourage attitudes believed to be associated with managerial effectiveness (Powell \& Yalcin, 2008). Being a manager is a job and job-specific training is about improving effectiveness in a current role (Warr, 2002). However 
PROBLEMS

OF MANAGEMENT

IN THE $21^{\text {st }}$ CENTURY

Volume 4, 2012

10

a problem that often emerges in reality is the manager's desire for organization specific or personalized training and the trainer's need to design training that is appropriate for a group to deal with (Bates \& Davis, 2010). Nonaka and Takeuchi (2011) are much more outrageous in pointing to problems in management training since they criticize overall managerial education and claim that there's something wrong with the way business schools, companies, and leaders are developing managers. They argue that managers tend to rely in everyday activities on explicit knowledge, because it can be codified, measured, and generalized. Such a viewpoint can be partly explained by explicit knowledge being a core of industrial age management or as has stated: "we are all products of industrial aged schools and most of us developed our survival skills for industrial-age institutions" (Senge, et al., 2003, p. 34). Moreover, also Greiner, Bhambri and Cummings (2003, p. 404) point to the serious problem related to leading business schools, which emphasize research over teaching; and according to their view "most new faculty members are selected for their content knowledge and research skills, not for their expertise in teaching management practice". Pfeffer and Sutton (1999) use the term "knowing doing gap" and share the view that managers tend to know too much and do too little, resulting in smart plans and ideas that rarely get implemented. Greiner, Bhambri and Cummings (2003, p. 404) blame in this modern business schools "where students primarily learn how to think and talk smart, but not to act smart".

In this context non-formal management training and development business sector could fulfill the "knowing - doing gap" and building bridges between knowledge and practice by applying more flexible approaches to the development of course programs and teaching methods. However since trainers' background is often also an industrial-age business school, there are several challenges similar to university and business schools that a training business in training practical managers has to cope with. According to Berggren and Söderlund (2010) these are: (a) the challenge of rigor, use of theory, (b) the challenge of instrumentality and personal learning depth; and (c) the challenge of relevance and realization of lessons learned. Training programs relevance to real life situations seems to be the concern of trainees, also stressed as a need by Estonian managers while assessing management training and education (Enterprise Estonia, 2011). The latter reflects that programs and method used so far have not been motivating enough or could have been stronger related to company specifics. Additionally, a dilemma facing several training businesses is time restriction. As a rule practicing managers have limited time resource and company specific or their individual level expectations make it challengeable for a trainer to ensure the desired outcome. In terms of attitudes and skills acquisition the effect can be seen in certain time perspective, thus effectiveness of a short term, single training course might not be measurable at the time when training ends. All things considered training effectiveness is determined by the complex and interrelated set of factors like: clearly communicated goals, training programs, methods, trainer's capabilities, trainees' motivation and many other. Aziz and Ahmad (2011) suggest that training program design should be taken into serious account and in order to keep up motivation they point out following program characteristics that stimulate training motivation: training reputation, appropriate training design, option to voluntary attendance, and the relevance of training for job-, career-, and personal-related needs. Program characteristics are thought to help to design meaningful programs for participants. Meaningful programs can be created when the program contents are tailored to the specific needs of a target group, for example considering the specific needs of a small firm and large-sized firm managers and limitations set by their busy agendas (Ylinenpää, 2005).

The satisfying result is also determined by the appropriate choice of methods. Bourner (1997) suggests that the choice depends on the learning aim since different teaching methods are appropriate to different learning aims. When practicing managers focus more on training actions that are instantly applicable and help to acquire tacit knowledge that is hard to learn from 
the books the trainers need to have competency in a wide set of methods. In recent literature as well in managing training practice coaching as a learning method is more and more widely used in non-formal training sector next to traditional methods (lecture, reading, seminar, role-playing group project, case study, etc.). Business coaching is defined as "the process of engaging in regular, structured conversation with a client: an individual or team who is within a business, profit or nonprofit organization, institution or government and who is the recipient of business coaching. The goal is to enhance the client's awareness and behavior so as to achieve business objectives for both the client and their organization" (Wordlwide Association of Business Coaches, 2012). In the framework of business coaching the term executive coaching defined by Stern (2004) as an experiential, individualized, leadership development process that builds a leader's capability to achieve short and long-term organizational goals: conducted through oneon-one interactions, driven by data from multiple perspectives, and based on mutual trust and respect also stands out in literature. Executive coaching is thought to be effective when provided professionally by external coaches (Ellinger et al., 2011). In its turn executive coaching increases the quality of workplace coaching, which places an importance to supervisor or manager as a facilitator of learning who enacts behaviors that enable employees to learn and develop workrelated skills and abilities (Hamlin, 2006). Coaching on group level seems to have similar traits with action learning where learners focus on actual organizational challenges and learn how to solve them more effectively (Powell \& Yalcin, 2008). Similarities could be also seen with storytelling, an approach suggested by Gherardi and Piggio (2007) is based on workshops where participants discuss their work experiences, analyze them and rewrite new scenarios. There is certainly some overlap of methods used in practice, but the common feature is that they are learner-centered and generate self-reflection as well as critical thinking. Extensive use of these methods in practice of management training could be related to soft skills or social skills development becoming more significant compared to hard business skills commonly related to technical skills. Soft skills like listening, communication, teamwork, leadership, emotional intelligence are underemphasized by management education critics but Hughey and Mussnug (1997) argue that soft skills trainings are often not put into practice. Weber and Finley (2008) find that people learn soft skills by life, but professionals hone them by training, thus it is only natural that managers have realized the need for soft skills and are planning to train those.

Focus on social skills requires integrating appropriate methods and techniques with the program meaningful for the participants thus setting high level standards to the trainer's instruction skills, which is seen as an interrelated link in the chain leading to performance improvement (Wick, Pollock \& Jefferson, 2009). Trainer's skills and performance influences trainees' level of engagement and motivation in transfer of material (Goldstein \& Ford, 2002). Qualities of a training professional according to Kalargyrou and Woods (2011) are: teamwork, inspiration and motivation, creativity, mentoring, measuring and evaluating outcome, consistency in training and love and passion. They refer to similarities of Rae (2002) research who has emphasized in earlier study that training competencies important to trainers were: organizational knowledge, knowledge of management roles and functions (responsibilities and authority), training knowledge, program preparation skills, technological skills, people skills, commitment to training and development of people, creativity to increase effectiveness by using different ways of disseminating information, self-development, humor, and self-confidence.

Another factor determining training effectiveness is training business leadership and strategy. The extent to what managers of non-formal training businesses are enable to facilitate knowledge sharing in their company eventually increases competitiveness of their business, trainers and trainees. Knowledge sharing and continuous learning are seen as central elements of organizational learning and key factors for succeeding in turbulent market (Harvey \& Denton, 1999; Senge, 1990; Wang \& Ahmed, 2003). It is stressed that the adoption of learning as a central competence of the company is a collective responsibility and it will only happen 
PROBLEMS

OF MANAGEMENT

IN THE $21^{\text {st }}$ CENTURY

Volume 4, 2012

as a result of a carefully designed strategy and shared management objectives (Lopez, Peòn \& Ordás, 2006). One of the benefits of increasing collective responsibility is employees' identity with their organization. Earlier studies have shown that employees with strong identity have a positive attitude towards the organization (Mael \& Ashforth, 1992) and are more satisfied with their job (Van Knippenberg \& Van Schie, 2000). Thus the latter is the cornerstone of any organization including management and training and development businesses.

All things considered management training and development businesses' activities are influenced by set of mutually interrelated factors of external and internal environment. The present exploratory study focuses on factors like: programs, methods, trainers and company developmental issues (Figure 1).

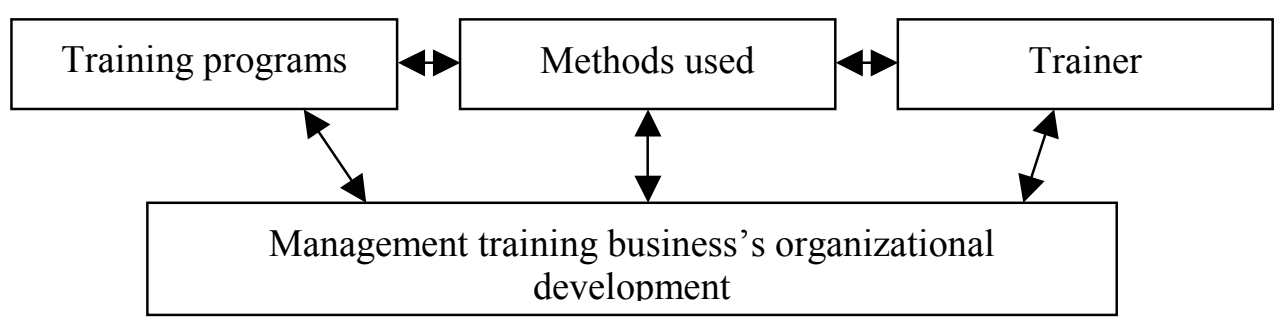

\section{Figure 1: Main mutually interrelated research issues in observing non-formal management training businesses.}

\section{Methodology of Research}

Qualitative study for exploring and documenting the current level of non-formal management and personnel training businesses' activities based on website information was carried out. Exploratory study was used because it enables making the preliminary investigation that could highlight some essential aspects for future studies (Yin, 1994). The study focused on programs, methods, trainers and organizational development issues of non-formal management training business in Estonia. The study had the following phases:

- Development of focus questions and goals,

- Supervision of website observers,

- Selection of websites,

- Conducting the observation,

- Presenting initial observation results,

- Follow-up observation,

- Analysis of comparable results and conclusions.

For the observation four focus issues with relevant research objectives were developed (Table 2). 
Table 2. Observation focus issues and their objectives.

\begin{tabular}{|c|c|c|}
\hline No & Keyword of a focus question & Objective \\
\hline 1. & Programs & Gain overview of the most offered programs and topics. \\
\hline 2. & Methods & Explore training methods referred to on websites. \\
\hline 3. & Trainers & Gain information on trainers' background. \\
\hline 4. & Organizational development & $\begin{array}{r}\text { Gain information about organizational development and the extent to } \\
\text { what a company casts light on its self development. }\end{array}$ \\
\hline
\end{tabular}

Training companies were found on random basis using the Estonian Internet Catalog and Search System - NETI (www.neti.ee). The major selection criterion was "management training" as a keyword. The overall sample consisted of 26 companies' websites including 3 on universities' continuing education units (one university was a private university thus a relevant unit functioned as a separate business integrated with university).

\section{Results of Research}

Observation of the training businesses websites showed that training programs and courses were the most extensively delivered information. Dominant feature was a relatively big number of programs reaching up to 80 different names and more than 100 in case the training company was an affiliate of an international training and consultation firm (one company in a sample). Orientation towards soft skills development clearly stood out (Table 3).

Table 3. Soft and hard skills representation on management training programs.

\begin{tabular}{|c|c|}
\hline Skills & Representation on websites \\
\hline $\begin{array}{l}\text { Soft skills (teamwork, cooperation, motivation, supervi- } \\
\text { sion, leadership, principles of management, human re- } \\
\text { source management, service, marketing, sales, conflict } \\
\text { resolution, presentation skills, self-development, etc.) }\end{array}$ & Stronger represented \\
\hline $\begin{array}{l}\text { Hard skills (finance, accounting, production, logistics, } \\
\text { etc.) }\end{array}$ & Less represented \\
\hline
\end{tabular}

Also teamwork skills programs were similarly frequently represented. Programs on finance, accounting and marketing where mostly targeted to specialists and less moderately represented among programs targeted to managers. Skills, related to technical knowledge and abilities were mostly found on websites of universities' continuous education thus less represented on training businesses websites. It was also observable that universities offer the same level programs with similar outcomes to their full-time students.

Sales skills and marketing programs were also less represented. As for target groups, all observed websites determined their target group to be managers, middle-managers, specialists or all organizations private and public, only $1 / 3$ emphasize their orientation toward top managers. 
PROBLEMS

OF MANAGEMENT

IN THE $21^{\text {st }}$ CENTURY

Volume 4, 2012

As for presenting teaching methods on the websites universities excluding a private one, stood out for presenting more traditional training methods: lecture, independent work, exam, etc. The rest introduced a broad spectrum of methods where lectures integrated with the actions, practical works and group discussions were promised... Approximately $1 / 3$ of the reviewed websites presented coaching as a method however various definitions of the term were introduced.

Surprisingly few presented eLearning and interactive tests or provide any other form of two-way communication on website. Similarly modestly were at the time of the study represented links to social media networks (Twitter, Facebook, YouTube, etc.). These links however were found on a private university website, which in author's opinion reflects its clear orientation to global market. Major findings of the training businesses presentation of programs, methods, trainers and organizational development issues on websites are given in Table 4.

Table 4. Major findings on websites across focus questions.

\begin{tabular}{|c|c|c|}
\hline No & $\begin{array}{l}\text { Keyword of a focus } \\
\text { question }\end{array}$ & Major findings \\
\hline 1. & Programs & $\begin{array}{l}\text { Broad scope of program topics and course names. Soft skills training programs } \\
\text { (teamwork, leadership, cooperation, customer service) stood out. Marketing and } \\
\text { sales programs less represented. Finance management programs are dominating on } \\
\text { universities' websites. } \\
\text { Top manager as a target group modestly represented. }\end{array}$ \\
\hline 2. & Methods & $\begin{array}{l}\text { Broad spectrum of methods - mostly active learning. } \\
\text { Public university websites stand out with more traditional methods like lecture, exam, } \\
\text { etc. Considerable amount of training companies offers coaching as a new method. } \\
\text { E-learning modestly represented. }\end{array}$ \\
\hline 3. & Trainers & $\begin{array}{l}\text { Trainer's background communicated by resumes, short descriptions, experience, etc. } \\
\text { Few do not reflect any information about trainers rather than their name and job title. } \\
\text { Contracted co-trainers as specialists working for some other institutions are used by } \\
\text { nearly half of the training companies. } \\
\text { University continuing education websites give little information about their trainers' } \\
\text { lecturers. }\end{array}$ \\
\hline 4. & $\begin{array}{l}\text { Organizational } \\
\text { development }\end{array}$ & $\begin{array}{l}\text { Modestly or not presented on websites. Mostly success stories of some projects or } \\
\text { trainers' are given. }\end{array}$ \\
\hline
\end{tabular}

The presentation of trainers turned out to be the most multifaceted issue communicated on websites because similar trends were hard to find. Less than half delivered information about trainer's educational background, few gave full resumes. About half did not communicate anything about trainer's education. In latter case professional competence was emphasized with job title, position or given rewards. Trainer's connectedness with the company is another aspect that was poorly communicated however it was clearly observable that majority were using experts on contract bases. There were few websites that clearly stated using professional cotrainers network reaching up to 30 (the case of one of the largest and oldest Estonian training companies). Universities shared minimum amount of information about teachers on their websites.

In regard to training business's organizational development the observation showed that most of the reviewed management training businesses in Estonia were not considered important to reflect this type of information on their website. Almost half of them described single successful projects or stressed trainers' developmental paths instead of company development. 


\section{Discussion}

Management training as skills oriented learning has an important role in management development. Managerial skills can be acquired from everyday practice assisted by courses provided by management training businesses. The present study of management training businesses websites brought forward soft skills dominance, which according to Muir (2004) are related to attitudes and behaviors. The same can be also said for teamwork and teamwork skills programs were similarly frequently represented. This reflects the importance of social and cognitive competencies in managerial work (Watson, 1994). Teamwork and cooperation competencies were also the primary needs expressed by the managers (Enterprise Estonia, 2011) thus the demand meets the supply. Another reason could be the perceived high quality of soft skills trainings offered by management training businesses.

The findings of the study showed that universities' continuous education focused on programs on finance management and accounting, which according to (Muir, 2004) can be seen as hard skills, related to technical knowledge and abilities required to perform specific job. The latter reflects universities expertise and long time traditions on delivery of knowledge in this field, since full-time students were offered the similar programs.

It is surprising however that sales and marketing programs were less represented on websites. At the same time research findings conducted by Enterprise Estonia show that managers are looking for better quality of sales trainings (Enterprise Estonia, 2011). This means that non-formal training businesses should consider focusing on designing up-to date sales and marketing programs. The lack of marketing and sales programs could be partly explained by lack of experts or trainers. On the side the need for sales training may reflect specialists and middle-managers prior knowledge gained from university programs where the dominant focus was on narrow analytical skills, stylized treatment of complex issues by teachers with no direct business experience (Reibstein, Day \& Wind, 2009). Programs teaching "old" techniques are not perhaps satisfying neither for the trainer nor or for the trainee and "new" programs integrating new skills were being on an experimental level at the time of the study. When looking for evidence showing the overall satisfaction of managers with management training businesses in Estonia the assessments given on both: Estonian and foreign owned training programs were relatively low: on the 5 point scale the average indicators stayed 2.5-3.4 (Enterprise Estonia, 2011). This indicates managers' attitude to training businesses and on the other hand is a signal for training businesses need for developing their quality. The major reasons mentioned in for dissatisfaction is the lack of company specifics and not meeting the expectations, which confirms that in terms of relevance training businesses just like university business schools are struggling with challenges of rigor and relevance mentioned earlier in this article by Berggren and Söderlund (2010).

Based on the big number of programs and large specter of target groups and no clear distinction made between them it can be said that due to the smallness of the country with population of 1.320.976 (Statistics Estonia, 2011) training companies are striving for capturing the biggest possible share of the local market offering variety of programs to variety of target groups from specialist to top management. The specialization does not seem to be typical. As the top level management is not the primary target group, it is possible that there is moderate demand for trainings from top managers. This can be explained by the view of Longenecker \& Fink (2005) who claim that management training can be seen as a "nuisance", a "distraction", or even a "bother" when more pressing "hot" issues are at hand. Fill \& Mullins (1990) find that: "training can be seen as an unplanned activity with low priority". They suggest however that lack of planning can be central not only to training but also to the organization as a whole. Researchers have repeatedly expressed the idea that senior executives must develop an understanding of what management training and development can and cannot do for them. 
PROBLEMS

OF MANAGEMENT

IN THE $21^{\text {st }}$ CENTURY

Volume 4, 2012

16

Limited time resources often define high expectations however managers must come to understand that periodic programs are an important tool for them in improving business results (Bolt, 1987).

Broad spectrum of methods with action learning strongly communicated on websites confirms (Powell and Yalcin, 2008) understanding that action learning is considered to offer additional benefits. Next to action learning coaching was also dominating however various awkward definitions of the term reflects either the confusion in terminology in relevant literature or trainers' different background knowledge on this field. On the other hand coaching dimension in management training is a positive trend as it can minimize superficiality at institutionally sponsored training courses (Wright \& Tao, 2001). Findings from earlier research by Moen and Skaalvik (2009) indicate a significant effect of external executive coaching on psychological variables affecting performance such as self-efficacy, goal setting, intra-personal causal attributions of success and need satisfaction. For example intention to develop coaching was mentioned by mangers in the survey conducted in the UK (Ketter, 2011), but it has not been mentioned as a training need by managers in Estonia (Enterprise Estonia, 2011). Surprisingly few presented eLearning opportunities or links to social networks at the time of the study on their websites. The current study does not bring forth the reasons for this but speculations can be made that training businesses were very much oriented to local and regular customer base or/and had not realized yet the power of modern communication channels in attracting new. Another speculation here is that at the time of the study management training and development businesses were still suffering from economic downturn and confusion and/or had lack of new knowledge and communication skills in using new media. Another reason could be perhaps the study was conducted at the time when businesses were re-forming their strategies and websites were not renewed appropriately.

\section{Conclusion}

The study of 26 management training websites brought forward the scope of non-formal management training businesses programs, methods, trainers and organizational development issues. Since little specialization across sectors was noticeable it allows speculating that training companies tend to offer management level trainings of general knowledge. On the other side orientation toward tailor made trainings as a common feature reflects readiness to handle company specifics, since managerial skills are hard to learn in isolation of context

The common feature of the programs observed was soft skills (team building, cooperation and leadership) dominance over hard skills like finance and accounting. However university continuous education websites stood out for offering long-term programs on finance management. This brings forth the strengths and weaknesses of management training businesses. As for methods universities, except for private one stood out for indicating more traditional academic study methods like lectures and exams. On training business websites coaching as a method was found to be a growing trend that indicates the important role of personal development and deep learning that can be achieved with the method. On the other hand coaching dominance is quite expected in the context where soft skills are stronger represented in programs. Most training companies are modest about describing their organizational development. Also trainer's connectedness with the company was found to be fuzzy issue. For the majority of cases it was noted that management training businesses were referring to specialists employed by some other institution. This indicates that many Estonian training companies are using the know-how of other institutions and are functioning more like mediators not creating sustainability for their business.

The findings of a current exploratory study exemplify the state of management training businesses activities in Estonia in terms of program topics, methods, trainers and company 
development issues. The results of the current exploratory study could be useful for researchers and HR and training managers providing preliminary understandings of typical features of nonformal management training and development Estonia.

\section{Limitations}

Being exploratory study the findings here cannot be conclusive, they highlight the nonformal training businesses activities in terms of programs, methods, trainers and organizational development reflected on websites. The interpretations here need to be studied further in integration with other methods (questionnaires or interviews with trainers and managers) that would shed more light on non-formal management training issues in Estonia.

\section{References}

Ajuogu, M. O. (1993). The main constituents in managerial development. Education + Training, 22 (1), 27-30.

Andersson, T. (2008). Personal growth and sensitivity training - fashions in management and management research. International Studies of Management and Organization, 38 (2), 61-82.

Aspin, D. N., \& Chapman, J. D. (2000). Lifelong learning: concepts and conceptions. International Journal of Lifelong Learning, 19 (1), 2-19.

Aziz, S. F. A., \& Ahmad, S. (2011). Stimulating training motivation using the right training characteristic. Industrial and Commercial Training, 43 (1), 53-61.

Barnett, M. (2007). (Un)Learning and (mis) education through the eyes of Bill Starbuck: An interview with Pandora's playmate. Academy of Management Learning and Education, 6, 114-127.

Bates, L. D., \& Davis, J. T. (2010). The application bridge: A model for improving irainee engagement in training process. International Journal of Management, 27 (3), part 2 (December), 770-776.

Berggren, C., \& Söderlund, J. (2011). Management Education for Practicing Managers: Combining Academic Rigor with Personal Change and Organizational Action. Journal of Management Education, 35 (3), 377-405.

Bolt, J. F. (1987). Trends in management training and executive education: The revolution continues. Journal of Management Development, 6 (5), 5-15.

Bourner, T. (1997). Teaching methods for learning outcomes. Education + Training, 39 (9), 344-348.

Colby, A., Ehrlich, T., Sullivan, W. M., \& Dolle, J. R., (2011). Rethinking Undergraduate Business Education: Liberal Learning for the Profession. The Carnegie Foundation for the Advancement of Teaching. San Francisco CA: Jossey-Bass.

Coombs, P. H., \& Ahmed, M. (1974). Attacking Rural Poverty: How Nonformal Education can Help. Baltimore: John Hopkins University Press.

Creating People Advantage. (2009). How to tackle the major HR challenges during the crisis and beyond. The Boston Consulting Group, Inc. /European Association for People Management, June 3.

Datar, S. M., Garvin, D. A., \& Cullen P. G. (2011). Rethinking the MBA: Business education at crossroads. Journal of Management Development, 30 (5), 451-462.

Ellinger, A. D., Ellinger, A. E., Bachrach, D. G., Wang Y. L., \& Baş, A. B. E. (2011). Organizational investments in social capital, managerial coaching, and employee work-related performance. Management Learning, 42 (1), 67-85.

Enterprise Estonia. (2011). Retrieved 25/05/2011, from http://www.eas.ee/images/doc/sihtasutusest/ uuringud/ettevotlus/easi-juhtimisuuring-2010_eas-i_final.pdf. (In Estonian).

Fill, C., \& Mullins, L. (1990). The effective management of training. Industrial and Commercial Training, $22(1), 13-26$. 
PROBLEMS

OF MANAGEMENT

IN THE $21^{\text {st }}$ CENTURY

Volume 4, 2012

18 Fox, S. (1997). From Management Education and Development to the study of Management Learning. In

J. Burgoyne, \& M. Reynolds, (Eds.), Management Learning Integrating Perspectives in Theory and Practice (pp. 21-37). London: Sage Publications.

Gardiner, H. P., \& Kline, T. J. B. (2007). Development of the Employee Lifelong Learning Scale (ELLS). PAACE Journal of Lifelong Learning, 16, 63-72.

Gherardi, S., \& Piggio, B. (2007). Tales of ordinary leadership: A feminist approach to experiential learning. In M. Reynolds, \& R. Vince (Eds.), The handbook of experiential learning \& management education (pp. 155-168). Oxford, England: Oxford University Press.

Goldstein, I. L., \& Ford, J. K. (2002). Training in organizations: Needs assessment, development, and evaluation (4th Ed.). Belmont, CA: Wadsworth.

Gray, C., \& Mabey, C. (2005). Management development. Key differences between small and large business in Europe. International Small Business Journal, 23 (5), 467-485.

Greiner, L. E., Bhambri, A., \& Cummings, T. G. (2003). Searching for strategy teaching strategy. Academy of Management Learning and Education, 2 (4), 402-420.

Hamlin, R. G., Ellinger, A. D., \& Beattie, R. S. (2006). Coaching at the heart of managerial effectiveness: A cross-cultural study of managerial behaviours. Human Resource Development International, 9 (3), 305-331.

Harvey, C., \& Denton, J. (1999). To come of age: The antecedents of organizational learning. Journal of Management Studies, 36 (7), 897-916.

Hughey, A.W. \& Mussnug, K. J. (1997). Designing effective employee training programmes. Training for Quality, 5 (2), 52-57.

Indradevi, R. (2010). Training for most capable workforce. A case study. Advantages in Management, 3 (12) (December), 49-54.

Kalargyrou, V., \& Woods, R. H. (2011). Wanted: training competencies for the twenty-first century. Contemporary Hospitality Management, 23 (3), 361-376.

Ketter, P. (2011). Skills development increasingly critical for UK managers. $T+D$ American Society for Training and Development, 22 (February).

Klein, K., \& Ziegert, J. (2004). Leader development and change over time: a conceptual integration and exploration of research challenges. In D. V. Day, S. J. Zaccaro, \& S. M. Halpin (Eds.), Leader Development for Transforming Organizations (pp. 359-382). NJ: Lawrence Erbaum Associates, Hillsdale.

Knezevic, B., Renko S., \& Bach, M. P. (2011). Web as a customer communication channel in the confectionery industry in South Eastern European countries. British Food Journal, 113 (1), 1736.

Longenecker, C. O., \& Fink, L. S. (2005). Management training: Benefits and lost opportunities (part II). Industrial and Commercial Training, 37 (2), 73-79.

Lopez, S. P., Peòn, J. M. M., \& Ordás, C. J. V. (2006). Human resource management as a determining factor in organizational learning. Management Learning, 37 (2), 215-239.

Mael, F. A., \& Ashforth, B. E. (1992). Alumni and their alma mater: A partial test of the reformulated model of organizational identification. Journal of Organizational Behavior, 13 (2), 103-123.

McDowall, A., \& Saunders, M. N. K. (2010). UK managers' conceptions of employee training and development. Journal of European Industrial Training, 34 (7), 609-630.

Mabey, C., \& Finch-Lees, T. (2008). Management and Leadership Development. London: Sage Publications Ltd.

Minzberg, H. (2004). Managers not MBAs. A hard look at the soft practice of managing and management development. San Francisco, CA: Barrett-Koehler Publishers.

Minzberg, H. (2011). From Management Development to Organization Development with Impact. OD Practitioner, 43 (3), 25-29.

Moen, F., \& Skaalvik, E. (2009). The effect from executive coaching on performance psychology. International Journal of Evidence Based Coaching and Mentoring, 7 (2), 31-49. 
Muir, C. B. D. (2004). Learning soft skills at work. Interview with Annalee Luhman. Business Communication Quarterly, 67 (1), (March), 95-101.

Nonaka, I., \& Takeuchi, H. (2011). The wise leader. How CEOs can learn practical wisdom to help them what's right for their companies and society. Harvard Business Review, May, 58-67.

Patterson, M., West, M. Lawthorn, R., \& Nickell, S. (1997). Impact of people management practices on business performance. Issues in People Management, 22. London: Institute of Personnel and Development.

Pfeffer, J. (1994). Competitive advantage through people. Boston, MA: Harvard Business School Press.

Paauwe, J., \& Williams, R. (2001). Seven key issues of management development. Journal of Management Development, 20 (2), 90-105.

Powell, K. S. \& Yalcin, S. (2010). Managerial training effectiveness. A meta-analysis 1952-2002. Personnel Review, 39 (2), 227-241.

Rae, L. (2002). Trainer assessment: A guide to measuring the performance of trainers and facilitators. Farnham: Gower Publishing.

Reibstein, D. J., Day, G., \& Wind, J. (2009). Guest editorial: Is marketing academia losing its way? Journal of Marketing, 73, 1-3.

Rogers, A. (2005). Non-Formal Education: Flexible Schooling or Participation Education? New York, USA: Springer Science + Business Media, Inc.

Senge, M. P. (1990). The Fifth Discipline. The art of practice of the learning organization. New York: Random House.

Senge, P., Cambron-McCabe, N., Lucas, T. Smith, B., Dutton J., \& Kleiner, A. (2003). Schools that learn. A Fifth Discipline fieldbook for educators, parents and everyone who cares about education. London: Nicholas Brealey Publishing.

Sharp, L. (2001). Positive response action: The ultimate goal of website communication. Journal of Communication Management, 6 (1), 41-52.

Statistics of Estonia. Retrieved 20/02/2012 from http://www.stat.ee/main-indicators

Stern, L. R. (2004). Executive coaching: A working definition. Consulting Psychology Journal: Practice and Research, 56 (3), 154-162.

Van Knippenberg, D., \& Sleebos, E. (2006). Organizational identification versus organizational commitment: Self-definition, social exchange, and job attitudes. Journal of Organizational Behavior, 27 (5), 571-584.

Vorvoreanu, M. (2008). Website experience analysis: A new research protocol for studying relationship building on corporate websites. Journal of Website Promotion, 3 (3/4), 222-249.

Wang, C. L., \& Ahmed, P. K. (2003). Organizational learning: Acritical review. The Learning Organization, 10 (1), 8-17. In P. Warr (Ed.), Psychology at Work. (2002). London: Penguin Books.

Warr, P. (2002). Learning and Training. In P. Warr (Ed.), Psychology at Work. London, U.K: Penguin Books.

Watson, T. (1994). In Search for Management. London: Routledge.

Weber, M. R., \& Finley, D. A. (2009). An exploratory study identifying soft skill competencies in entrylevel managers. Tourism and Hospitality Research, 9, 353-361. doi: 10.1057/thr.2009.22.

Wick, C., Pollock R., \& Jefferson, A. (2011). The new Finish line for learning training and development. $T+D$, American Society for Training and Development, (July), 64-69.

Worldwide Association of Business Coaches. Retrieved 01/03/2012 from http://www.wabccoaches.com

Wright, P. C., \& Tao, F. K. C. (2001). The missing link: Coaching as method of improving managerial skills in smaller businesses in Asia. Career Development International, 6 (4), 2181-2225.

Xi, Y., Zhuang, Y., Huang, W., She, C., \& Zhan, Z. (2007). The quality assessment and content analysis of corporate websites in China: An empirical study. International Journal of Information Technology \& Decision Making, 6 (2), 389-405.

Yin, R. K. (1994). Case Study Research: Design and Methods. Thousand Oaks, CA: Sage Publications. 
IN THE $21^{\text {st }}$ CENTURY

Volume 4, 2012

Yiu, L., \& Saner, R. (2009). Assessment and accreditation of non-formal management education and development programmes. In S. J. Armstrong, \& C. V. Fukami (Eds.), Sage handbook of management learning, education and development (pp. 531-546).

Ylinenpää, H. (2005). If management can be learned, can learning be managed? Reflections on HEIbased management training in smaller firms. International Journal of Lifelong Education, 24 (6), 507-524.

Advised by Vincentas Lamanauskas, University of Siauliai, Lithuania

Received: May 04, 2012

Accepted: June 19, 2012
Maret Ahonen

MBA, PhD Student, Lecturer, Faculty of Economics and Business Administration, University of Tartu, Narva Rd. 4, Tartu, 51009, Estonia.

E-mail: Maret.Ahonen@ut.ee

Website: http://www.ut.ee 